\title{
PENGARUH PEMBERIAN JUS ALPUKAT TERHADAP TEKANAN DARAH PENDERITA HIPERTENSI DI BATOH WILAYAH KERJA PUSKESMAS LUENG BATA KOTA BANDA ACEH
}

\author{
Indah Yusra', Aripin Ahmad', Agus Hendra AL-Rahmad \\ 1,2,3 Jurusan Gizi, Politeknik Kesehatan Kemenkes Aceh, Jl. Soekarno Hatta, Kampus Terpadu Poltekkes \\ Kemenkes RI Aceh Lampeneurut, Aceh Besar. Telp.065146126.
}

\begin{abstract}
ABSTRAK
Hipertensi merupakan faktor resiko utama dari perkembangan (penyebab) penyakit jantung dan stroke. Tekanan darah diastolik adalah tekanan darah pada saat jantung mengembang dan menyedot darah kembali. Prevalensi hipertensi secara nasional sebesar 31,7\%, di Aceh prevalensi hipertensi mencapai 9,2\%, di kota Banda Aceh prevalensi hipertensi mencapai 33,1\%. Tujuan penelitian mengetahui pengaruh Pemberian Jus Alpukat Terhadap Tekanan Darah Di Desa Batoh. Penelitian bersifat deskriptif analitik, dengan rancangan quasi eksperimental, sampel dalam penelitian penderita hipertensi berjumlah 20 orang secara metode purposive sampling. Uji statistik digunakan yaitu T-Test Dependen pada CI:95\%. Hasil penelitian bahwa rerata tekanan darah sampel sebelum pemberian jus alpukat adalah 95,75 mmHg dan Rata-rata tekanan darah sesudah pemberian jus alpukat adalah 83,25. Terdapat selisih penurunan tekanan darah 12,5 mmHg. Terdapat pengaruh yang signifikan pemberian jus Alpukat terhadap penurunan tekanan darah, $P=0,000(P \leq 0,05)$. Kesimpulan yaitu pemberian tritmen jus alpukat berpengaruh terhadap penurunan tekanan darah. Diharapkan kepada masyarakat agar dapat mempertimbangkan untuk mengkonsumsi jus alpukat untuk menurunkan tekanan darah pada penderita hipertensi.
\end{abstract}

Kata kunci : Jus Alpukat, Tekanan Darah, Penderita Hipertensi

\begin{abstract}
Hypertension is a major risk factor of development (cause) of heart disease and stroke. Diastolic blood pressure is the blood pressure when the heart expands and suck the blood back. National prevalence of hypertension of $31.7 \%$, the prevalence of hypertension in Aceh reached 9.2\%, in the city of Banda Aceh prevalence of hypertension reached 33.1\%. This study aimed to influence Avocado Juice Against Giving Blood Pressure In the village Batoh. Descriptive analytic study, with a quasi experimental design, sample study of 20 people with hypertension are purposive sampling method. The statistical test used is the T-Test Dependent on CI: 95\%. The results of the research that the average blood pressure of the samples prior avocado juice was $95.75 \mathrm{mmHg}$ and the average blood pressure after the administration was 83.25 avocado juice. There is a difference in blood pressure reduction of $12.5 \mathrm{mmHg}$. There is a significant effect giving Avocado juice to the decrease in blood pressure, $P=0.000$ $(P \leq 0,05)$. Conclusion tritmen avocado juice that is giving effect to the decrease in blood pressure. It is expected to consider the community to be able to consume the avocado juice to lower blood pressure in hypertensive patients.
\end{abstract}

Keywords : Avocado juice, Tension, Hypertension Patients 